\title{
Evaluation of The Effect of Pasak Bumi (Eurycoma longifolia Jack) to Increase Androgen Levels
}

\author{
Hurip Pratomo ${ }^{1}$
}

\begin{abstract}
Background:The ability of reproductive disorders in men and experimental male rat is characterized among other things by a decrease in androgen such as testosterone levels. Materials of pasak bumi root (Eurycoma longifolia Jack) increased libido behavior of experimental male rat. Libido associated with higher levels of testosterone, it is therefore necessary to evaluate the effect of pasak bumi on androgen levels such as testosterone. Methods: Male rats at 9.00 am treated controls and pasak bumi, then at $14.00 \mathrm{pm}$ tempted with estrus female rats 10 minutes. Then, both control and pasak bumi blood samples were collected from male rat heart on day $1^{\text {st }}$ and day $3^{\text {rd }}$ at $14.15 \mathrm{pm}$. Measurement of testosterone levels were calculated using radioimmunoassay (RIA). Results: An increase in serum testosterone levels in the blood on day- $3^{\text {rd }}$ administration pasak bumi boiled water $18 \mathrm{mg} / 200 \mathrm{~g}$ dose significantly different than the control within day $1^{\text {st }}$ to $3^{\text {rd }}$. The average levels of testosterone administration control (boiled water of aquades) day $1^{\text {st }}=0.50 \mathrm{ng} / \mathrm{ml}$, day $3^{\text {rd }}=2.46$ $\mathrm{ng} / \mathrm{ml}$, increased markedly on pasak bumi treatment day $1^{\text {st }}=4.00$ $\mathrm{ng} / \mathrm{ml}$ and day $3=9.73 \mathrm{ng} / \mathrm{ml}$, (Duncan test, $\alpha=0.05$ ). Conclusions: Testosterone levels can be increased markedly after the consumption of the pasak bumi boiled water for 3 days.
\end{abstract}

Keywords-Pasak bumi, a dose of $18 \mathrm{mg} / 200 \mathrm{~g}$, testosterone.

\section{INTRODUCTION}

$\mathbf{S}$ ome adult males impaired vitality or reproductive impairments, including a decrease in the androgen hormone such as: testosterone. The public in Borneo Indonesia assumes traditionally that disorders can be corrected by using the root powder of pasak bumi (Eurycoma longifolia). The boiled water of pasak bumi increased the libido of male rats significantly on the $3^{\text {rd }}$ day[1]. The next research found cells of basophils increased in the pituitary meanwhile the number cells of acidophils still stabil, after dosing pasak bumi infusion $18 \mathrm{mg} / 200 \mathrm{~g} \mathrm{~mm}$ once every morning until the $3^{\text {rd }}$ day [2]. The research with immunohistochemical approached of folicle stimulating hormone (FSH) cells found pasak bumi maintained the number of basophils cells activity that produce the FSH hormone on the 3rd day administration [3]. The purpose of this study was: evaluation the effect of the pasak bumi root on increasing testosterone levels.

Pasak bumi is a tree that can reach $20 \mathrm{~m}$ life grows in Borneo. Lancet shaped leaves of pasak bumi with flat edge measuring $2.5-14.2 \times 0.7$ to $4.5 \mathrm{~cm}$. Odd pinnate compound leaves with the number of 11- 38 accumulate on the ends of twigs. Panicle shaped red flowers and fluffy. Yellow fruit reddish when young and becomes black when older. Extracts powder of pasak bumi root (Eurycoma longifolia) with a solvent such as water containing: phenolic compounds, tannins, polysaccharides, glycoproteins, and mucopolysaccharide, also includes eurycomanone and longilactone [4;5].

Level of testosteron in the blood always correlated with serum levels of luteinizing hormone (LH). The LH function in men and male animals that stimulates interstitial cells or Leydig cells in the testes to produce testosterone [6]. LH secretion from the anterior pituitary is mediated by stimulation of cyclic adenosine mono-phosphate (cAMP) and calmodulin synthesis [7]. Stimulation was allegedly played by one or some of the compounds of pasak bumi given on day 1 and day-3 such as eurycomanone and longilactone. I propose one or some compounds of the pasak bumi root serves as Gonadotropin releasing hormone-LH (GnRH-LH), so that the pituitary LH synthesis increased markedly. Furthermore, LH are secreted into the blood circulation. LH arrived in Leidig cells to activate or enhance the work of cells to synthesize testosterone. Testosterone in a relatively short time has been distributed by the bloodstream so that within 1 to 3 days had measurable improvement in the serum.

\section{METHODS}

\section{A. Laboratory animals}

Experimental animals using adult male white rats Rattus norvegicus Sprague Dawley strain aged $3 \frac{1}{2}$ months with a weight of 121-194 g. Rats were obtained from the laboratory animal of Indonesia food and drug supervision agencies. The number of 30 rats, for treatment as follows: 15 males white rats treated with pasak bumi every day, on days $1^{\text {st }}$ and $3^{\text {rd }}$, after the treatment was tempted to estrus females, sacrificed their each of five male $(n=$ replicates $=5)$ to take blood from the heart. Similarly, 15 males white rats to the control group performed with distilled water delivery schedules as treatment pasak bumi. A number of five female rats, estrus was selected to be used as a teaser. Before the pasak bumi was treated, white rats adapted in animal breeding rat cages in animal hospital Darmaga Bogor for 2 weeks. During the study rats were given food and water ad libitum.

\section{B. Pasak bumi materials}

Crude plant of pasak bumi root (Eurycomae longifolia Jack) derived from herbal market in Banjarmasin Borneo, hulled as in the manufacture of other herbal powder with modifications [8]. The wood from the root of pasak bumi relatively hard was washed and drained and cut into pieces with a length of $7 \mathrm{~cm}$, $2 \mathrm{~cm}$ wide and $2 \mathrm{~cm}$ thick. Pieces were dried in an oven at $50^{\circ}$ $\mathrm{C}$ for 5 days, then cut into small pieces using a sharp stainless knife. Root pieces of wood are then milled into powder using a specially milled to make flour and then filtered with a sieve mesh 50 (pore size $=300 \mathrm{~m}$ ). Crude plant of pasak bumi root (Eurycomae longifolia Jack) then stored in a jar in the dry cupboard [2].

\section{Experimental Design}

The experiment was conducted in animals laboratory in the animal hospital called Rumah Sakit Hewan (RSH) Darmaga Bogor under the supervision of Institutional Animal Care and 
Use Committee. Measurement of testosterone using radioimmunoassay (RIA) performed in the laboratory Mandapa Pajajaran street in Bogor . The male white rat, divided into two groups are: The control group ; 1). Control day $1^{\text {st }}$. 2). Control day $3^{\text {rd }}$, and the pasak bumi group; 3 ). Pasak bumi day $1^{\text {st }}$. 4) Pasak bumi day $3^{\text {rd }}$. Male white rat at 9:00 am given boiled water pasak bumi $18 \mathrm{mg} / 200 \mathrm{~g}$ bb dose on day $1^{\text {st }}, 2^{\text {nd }}$, and $3^{\text {rd }}$ respectively 5 replicates. Then, the male rats at $14.00 \mathrm{pm}$ seduced by an estrus female rat in a separate wire cage for 10 minutes. The control group did the same thing, except given distilled water $1 \mathrm{ml} / 200 \mathrm{~g}$ bb treated equally. The next, male rats anaesthetized using ketamine (containing ketamil) at 14:15 pm, then the blood was taken from the heart for the measurement of testosterone. Sampling of blood for testosterone measurements performed on days $1^{\text {st }}$ and $3^{\text {rd }}$ only.

\section{RESULT}

The results of measurements of testosterone levels in day- $1^{\text {st }}$ to day- $3^{\text {rd }}$ in male rats at estrus females seduced cage treated pasak bumi observation than control contained in Table 1 .

Table 1. Serum testosterone levels in the control and pasak bumi on day- $1^{\text {st }}$ to day- $3^{\text {rd }}$

\begin{tabular}{lll}
\hline No & Treatment & $\begin{array}{l}\text { Levels of } \\
\text { Testosterone } \\
\text { (ng/ml) } \\
\text { Mean } \pm \text { SD }\end{array}$ \\
\hline 1 & Control day $1^{\text {st }}$ & $0,50 \pm 0,57^{\text {a }}$ \\
2 & Control day $3^{\text {rd }}$ & $2,46 \pm 1,26$ a \\
3 & Pasak bumi day $1^{\text {st }}$ & $4,00 \pm 1,06$ a \\
4 & Pasak bumi day $3^{\text {rd }}$ & $9,73 \pm 2,42 \quad$ b \\
\hline
\end{tabular}

Description: Different superscript lowercase letters in the same column expressed a real difference at $95 \%$ level of confidence, (Duncan test, $\alpha=0.05$ ).

Serum testosterone levels increased significantly in the treatment doses pasak bumi $18 \mathrm{mg} / 200 \mathrm{~g} \mathrm{~mm}$ on day- $3^{\text {rd }}$, ie $9,73 \mathrm{ng} / \mathrm{ml}$ compared to the control treatment day $3^{\text {rd }}$, ie 2.46 $\mathrm{ng} / \mathrm{ml}$ (Duncan test, $\alpha=0.05$ ). Elevated levels of testosterone in the average control day $1^{\text {st }}$ and day $3^{\text {rd }}, 0.50 \mathrm{ng} / \mathrm{ml}$ which increased to 2.46 is still below the average increase in the level of testosterone in the treatment of pasak bumi day $1^{\text {st }}$ and day $3^{\text {rd }}$, which is $4.00 \mathrm{ng} / \mathrm{ml}$ increased to $9.73 \mathrm{ng} / \mathrm{ml}$ (Table 1)

Testosterone levels were not significantly different in the control of day-to-3 was statistically (Duncan test, $\alpha=0.05$ ) compared to control day-to- 1 . This phenomenon illustrates that under the influence of temptation treatment of estrous females continuously at 14:00 for 10 minutes once a day for 3 days did not significantly increase the release or secretion of testosterone into the bloodstream by Duncan test was a significant increase in the provision of treatment boiled water pasak bumi $18 \mathrm{mg} / 200 \mathrm{~g}$ bw. Testosterone levels that occurs in the pasak bumi treatment increased on day $1^{\text {st }}$ and day $3^{\text {rd }}$ higher than the control day $1^{\text {st }}$ and day $3^{\text {rd }}$. Significantly affect the pasak bumi increased testosterone synthesis in the Leydig cells, followed by secretion of testosterone into the blood circulation.

\section{DISCUSSION}

The findings of pasak bumi (Eurycoma longifolia) experiment explained that an increase in activity-producing cells in the pituitary LH rats treated pasak bumi. This was followed by an increase in the release of LH into the blood, so to the Leydig cells as LH destination cell. Following response was an increase in the activity of Leydig cells, thereby actively producing testosterone, which has been evidenced by an increase in testosterone levels in the blood serum on day- $3^{\text {rd }}$ treatment pasak bumi than day $1^{\text {st }}(4.00 \mathrm{ng} / \mathrm{ml}$ increased to $9.73 \mathrm{ng} / \mathrm{ml})$. Whereas in normal circumstances, total testosterone levels in adult male white rats varied from $0.5 \mathrm{ng}$ / $\mathrm{ml}$ to $5.4 \mathrm{ng} / \mathrm{ml}$ [9]. The possibility was suggested the compound of the root of pasak bumi such as: eurycomanone and longilactone or eurycomalactone in figure 1 serves as Gonadotropin releasing hormone-LH (GnRH-LH).

Androgen such as: Testosterone is required for the normal development of spermatozoa. Testosterone activate genes in Sertoli cells that trigger the differentiation of these cells in the progression of spermatogenesis spermatozoa as spermatogonia differentiation. Testosterone also affects the response axis response pathway hypothalamic-pituitary-adrenal (hypothalamic-pituatary-adrenal axis or HPA) [10]. Testosterone is also synthesized in amounts far less in female animals by the theca cells of the ovaries, by the placenta, and also by zone reticularis of the adrenal cortex in males and females $[11 ; 12]$. Total testosterone levels in adult male white rats varied from mean $0.5 \mathrm{ng} / \mathrm{ml}$ to $5.4 \mathrm{ng} / \mathrm{ml}$ in normal circumstances. Total testosterone levels of male white rat strain Sprague Dawley adult aged $3 \frac{1 / 2}{2}$ months in normal circumstances without being seduced estrous females means measured by RIA method was $0.5 \mathrm{ng} / \mathrm{ml}$, whereas a 4 month old male mice on normal total testosterone levels means is 0,8 $\mathrm{ng} / \mathrm{ml}$ [7].

Total testosterone levels of Wistar strain male rat aged 3 months to mature rat normally measured by RIA method means is $3,3 \mathrm{ng} / \mathrm{ml}$ [13]. Increased levels of testosterone can occur in a particular treatment, the male rat were placed in locations such as higher temperature habitats than the common habitat (from $23^{\circ} \mathrm{C}$ to $25^{\circ} \mathrm{C}$ ), the levels of total testosterone means increase more than $5.4 \mathrm{ng} / \mathrm{ml}$ to $11.4 \mathrm{ng} / \mathrm{ml}$ [9]. In contrast to total testosterone levels of male white rats, total testosterone levels in older men are ranged of $30 \mathrm{ng} / \mathrm{ml}$ to 100 $\mathrm{ng} / \mathrm{ml}$, whereas total testosterone levels in adult females is in the range of $3 \mathrm{ng} / \mathrm{ml}$ to $7 \mathrm{ng} / \mathrm{ml}[14 ; 15]$.

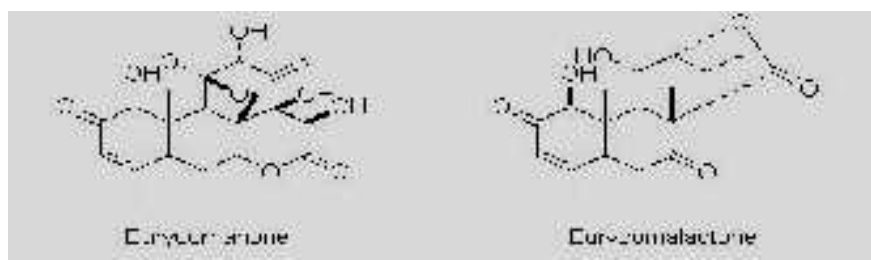

Fig. 1. Chemical structure of Eurycomanone and Eurycomalactone $[4 ; 5]$ 


\section{CONCLUSION}

The administration of pasak bumi boiled water 18 $\mathrm{mg} / 200 \mathrm{~g}$ dose $(=90 \mathrm{mg} / \mathrm{kg})$ once every morning; first day to day- $3^{\text {rd }}$ have increased the Leydig cells to synthesize androgen such as testosterone in male white rats.

\section{ACKNOWLEDGMENTS}

I was very grateful to the Laboratory animal veterinary hospital in Bogor Agricultural Institute. Also many thanks to Adi Winarto Ph.D., and the Research institutions and community services at the Open University (Universitas Terbuka, Indonesia), for their support on the success of this study.

\section{REFERENCES}

[1] Pratomo H, Winarto A, Rusdiyanto E. Kerja pasak bumi (Eurycoma longifolia. Jack) terhadap tingkah laku dan libido tikus putih jantan. J Matematika, Sains, dan Teknologi. 2010; 11 (1): pp 71-80.

[2] Pratomo, H, Supriatna I, Manalu W, Winarto A. 2011. Perubahan Sebaran Sel-Sel Asidofil dan Basofil Hipofisa Pengaruh Pemberian Pasak Bumi (Eurycoma longifolia Jack). J Matematika, Sains, dan Teknologi 12 (2): pp 80-91].

[3] Pratomo, H, Supriatna I, Manalu W, Winarto A. 2012. Tingkat Aktifitas Sel Endokrin Penghasil Folikel Stimulating Hormon (FSH) Terkait Pemberian Pasak Bumi (Eurycoma longifolia Jack). J Kefarmasian Indonesia. 1 (1): pp 1-10

[4] Ang HH, Lee KL. Effect of Eurycoma longifolia Jack on orientation activities in middle-aged male rats. Fund \& Clin Pharmacol., 2002; 16 (6) :479-481
[5] Ang HH, Hitotsuyanagi Y, Takeya K. Eurycolactones AC, novel quassinoids from Eurycoma longifolia. Pythochem tetrahedron. , 2000; 41 (35):6849-6853.

[6] EJ Squires. Applied animal endocrinology. Wallingford UK: CABI Publishing; 2003.

[7] Tantawy WHE, Abeer T, Omayma DE. Free serum testosterone in male rats treated with Tribulus alatus extract. Int Braz J Urol. 2007: 33: 554 559

[8] Indonesian Department of Health. Standardization of herbal drug preparations, Seminars and exhibitions of national working group of national Indonesian medicinal plants. Jakarta. ,2003; March 25 to 26.

[9] Favig EM, Foad O. Serum and plasma levels of total and free testosterone and sex hormone binding globulins of rats in growing in the below sea level Environtment of the Jordan valley. J Endocr. , 2009; 5 (2): 1-6.

[10] Mehta PH, AC Jones, Josephs RA. The social endocrinology of dominance: basal testosterone Predicts cortisol changes and behavior following victory and defeat. J Pers Soc Psychology. , 2008; 94 (6) :1078-93.

[11] Mooradian AD, Morley JE, Korenman SG. Biological actions of androgens. Endocr Rev. 1987; 8 (1): 1-28.

[12] Morgentaler A, Schulman C. Testosterone and prostate safety. Front Horm Res. , 2009; 37: 197-203.

[13] Kaspul. Testosterone levels of white rats (Rattus norvegicus L) after eating eggplant ulcers (Solanum torvum Sw). Bioscientiae. , 2007; 4 (1): $1-8$.

[14] Greenspan FS, Strewler GD. Appendix in Francis S.G and Gordon J. S (eds), Basic and clinical endocrinology. 5th ed. Prentice-Hall International Inc.. 1997. London.

[15] Ruswana A. Synthesis, Function and interpretation of the examination of the reproductive hormones. New York: Subdivision Fertility and Reproductive Endocrinology, Department of Obstetrics and Gynecology, Faculty of Medicine, Padjajaran University, 2005 Indonesia. 